\title{
In vitro evaluation of the vasodilatory activity of ethanol extracts of Eleutherine bulbosa bulbs and leaves
}

\author{
Ika Fikriah $^{1}$, Sjarif Ismail ${ }^{1,2}$, Khemasili Kosala ${ }^{1,2 *}$ \\ ${ }^{1}$ Department of Pharmacology, Faculty of Medicine, Mulawarman University, Samarinda, Indonesia. \\ ${ }^{2}$ Research Center for Natural Products from Tropical Rainforest (PUI-PT OKTAL), Mulawarman University, Samarinda, Indonesia.
}

\begin{tabular}{l}
\hline ARTICLE INFO \\
\hline Received on: $11 / 08 / 2020$ \\
Accepted on: $27 / 03 / 2021$ \\
Available online: $05 / 05 / 2021$ \\
\hline Key words: \\
Aorta, bulbs, Eleutherine \\
bulbosa, leaves, vasodilation.
\end{tabular}

\section{INTRODUCTION}

Eleutherine bulbosa (Mill.) Urb. (E. bulbosa), also termed Eleutherine americana Merr (Couto et al., 2016), belongs to the Iridaceae family and is widely available in Kalimantan under the local name Bawang Tiwai. It is usually used as food and has not been explored as a raw material for medicines or herbs with economic potential. An ethnobotanical search has revealed that the Kalimantan Dayak ethnic group has utilized this herb to reduce blood pressure (Mayasari et al., 2018; Syamsul et al., 2015). The E. bulbosa bulb (EBB) extract reportedly decreases blood pressure in hypertension-induced rats, causing vasodilation in the rat's aorta with endothelium in vitro (Hasimun et al., 2017; Yuliandra et al., 2018).

\footnotetext{
"Corresponding Author

Khemasili Kosala, Department of Pharmacology, Faculty of Medicine, Mulawarman University, Samarinda, Indonesia; Research Center for Natural Products from Tropical Rainforest (PUI-PT OKTAL), Mulawarman University, Samarinda, Indonesia.

E-mail:khemasili_k@yahoo.com
}

It has been known that vasodilation and vasoconstriction activities in blood vessels can be mediated by endotheliumdependent vascular smooth muscle cell (VSMC), by inducing endothelium to release endothelium-derived relaxing factor (EDRF) such as nitric oxide or prostacyclin or other EDRF, which is a vasodilator (Ismail et al., 2017), and also via endothelialindependent VSMC, by inhibiting the calcium channel which causes a reduction in $\mathrm{Ca}^{2+}$ influx (Luna-Vázquez et al., 2013). To date, there are no data showing whether the vasodilatory activity of EBB extract depends on the endothelium or not. Therefore, this study examined the vasodilatory activity of EBB extract to see whether it is endothelium-dependent. If proven otherwise, this herb has the potential to be developed as an antihypertensive drug in hypertensive patients with endothelial dysfunction as blood vessels with endothelial dysfunction will fail to show a vasodilatory effect if the drug action only occurs in the endothelium-dependent VSMC (Sandoo et al., 2010).

Currently, E. bulbosa leaves (EBLs) are disposed of as waste with no economic potential. A previous study has reported that EBLs possess antioxidant activity, as well as total phenolic content and secondary metabolites almost comparable with those present in bulbs (Pratiwi et al., 2013; Shi et al., 2018). (EBBs) 
demonstrate a strong vasodilatory potential as they grow from the bulging base of the leaf, warranting further investigation owing to its economic potential.

EBBss and EBLs are extensively available in East Kalimantan and possess economic potential. Hence, further research needs to be undertaken to discover herbal/medicinal raw materials with antihypertensive properties. Hypertension requires long-term therapy to control blood pressure and reduce the risk of stroke and coronary heart disease. Therefore, this plant presents immense opportunities as the number of individuals with hypertension in Indonesia, as well worldwide, continues growing and is estimated to reach more than 1.5 billion in 2025 (Kearney et al., 2005). Furthermore, this research is in accordance with the strategic plan of Mulawarman University in the Health Sector, on the prioritized topic of utilizing the East Kalimantan biodiversitybased plants for medicine and cosmetics, and further is in accordance with the vision and mission of the Medical Faculty of Mulawarman University.

The aim of this study was to examine if the vasodilatory activity is endothelial-dependent and to compare the vasodilatory activity of the extracts of EBBs and EBLs, bioassayed using isolated rat aorta.

\section{MATERIALS AND METHODS}

\section{Materials}

The bulbs and leaves of E. bulbosa were obtained from farmers in Samarinda City, East Kalimantan province, Indonesia. Bulbs demonstrating no rot or fungal growth were selected. The criteria for the leaves used were as follows: healthy, green, exposed to direct sunlight, and with no fungal growth or rot. Ethanol for extraction was purchased from PT Sumber Bahagia Surabaya. Ketamine for rat anesthesia was obtained from the Department of Pharmacy at AW Sjahranie regional general hospital Samarinda. Chemicals for making Krebs--Henseleit solutions were purchased from Sigma- Aldrich distributor in Surabaya. Carbogen gas (containing 95\% $\mathrm{O}_{2}, 5 \% \mathrm{CO}_{2}$ ) was purchased from PT Murni Gas Raya, Samarinda.

\section{Extracts preparation}

EBBs and EBLs, weighing $1 \mathrm{~kg}$ each, were selected according to the above-mentioned criteria and were washed and dried in a drying cabinet maintained at $60^{\circ} \mathrm{C}$. After drying, the bulbs and leaves were cut into small pieces and macerated for 3 days using an ethanol solvent. The collected filtrate was concentrated using a rotary evaporator at $60^{\circ} \mathrm{C}$, dried in a desiccator for 1 week, and placed in a $60^{\circ} \mathrm{C}$ oven. Finally, ethanol extracts of EBBs and EBLs were obtained for testing.

\section{Rat aortic ring preparation}

The bioassays were carried out using aortic rings isolated from male Wistar rats (Rattus norvegicus strain Wistar) aged 3-4 months and weighing 200-250 g, obtained from Pharmacology Laboratory, Faculty of Medicine of Mulawarman University. First, rats appearing healthy were randomly selected and anesthetized, followed by abdominal surgery. Next, the rat's aorta, separated from the surrounding tissue, was cut into a ring of $3 \mathrm{~mm}$ length, with its endothelial layer and the aortic smooth muscles intact, and put into an organ bath containing $10 \mathrm{ml}$ of Krebs-Henseleit solution, consisting of (mM) NaCl 118, $\mathrm{KCl} 4.7$, $\mathrm{CaCl}_{2} 2.5, \mathrm{MgSO}_{4} 1.2, \mathrm{KH}_{2} \mathrm{PO}_{4} 1.2, \mathrm{NaHCO}_{3} 24$, and glucose 11 , maintained at temperatures $37^{\circ} \mathrm{C}, \mathrm{pH} \mathrm{7.4}$, and diffused with carbogen gas. The study protocol was approved by the Health Research Ethics Committee (KEPK) of Mulawarman University (No. 159/KEPK-FK/IX/2019).

\section{Vasodilatory evaluation of EBB and EBL}

For EBB and EBL, vasodilation was bioassayed as described by Ismail and Yuniati (2016). The aortic integrity was evaluated by administering a methacholine solution, which induces vasodilation in the aortic ring. The aortic endothelium was mechanically removed as described by Ismail and Yuniati (2016), with the aorta pronounced without endothelium if $<10 \%$ vasodilation occurred after administration of the methacholine solution. Aortic precontraction was carried out using phenylephrine (PE) solution. After the plateaued peak of contraction was reached, $200 \mu \mathrm{l}$ of a $10 \%$ concentration of EBB, EBL, and extract solvent was administered, and the contractile response was observed. The evaluation was carried out on aorta with an intact endothelium, as well as aorta with the endothelium removed, repeated six times using six rats.

Following extract administration, changes in aortic tone were calculated as $\Delta \mathrm{g}$, defined as the difference between the final aortic tone after treatment and the initial tone at submaximal contraction (in grams). The percentage of aortic vasodilatory response was calculated using the following formula:

$$
\% \text { aortic vasodilation }=\frac{\Delta \mathrm{g}(\mathrm{g})}{\begin{array}{c}
\text { Initial tone at submaximal } \\
\text { contraction }(g)
\end{array}} \times 100
$$

Data regarding the percentage of aortic vasodilatation were statistically evaluated and are presented as mean \pm SD. Statistical analysis was carried out using a $t$-test and results were deemed as significantly different if the $p$-value was $<0.05$.

\section{RESULTS AND DISCUSSION}

The extraction of EBBs and EBLs with ethanol resulted in yields of $8.94 \%$ and $8.84 \%$ with water contents of $8.89 \pm$ 0.07 and $9.35 \pm 0.04$, respectively. This water content was within the tolerated limits established in the Indonesian Herbal Pharmacopoeia.

In this study, our results demonstrated that dimethyl sulfoxide) ethanol as an extract solvent could induce mild vasodilation in the aortic blood vessels with intact endothelium. Following the administration of extract solvents, increased contractions were observed in the endothelium-denuded aorta (Fig. 1A), with the $t$-test analysis revealing statistically significant differences $(p<0.05)$. This suggested that the extracting solvent could induce aortic vasodilation in blood vessels with intact endothelium.

In the EBB intervention study, EBB induced vasodilation in endothelium-denuded aortic blood vessels, as well as vasoconstriction in the aorta with intact endothelium (Fig. 1B), presenting statistically significant differences $(p<0.05)$ following the $t$-test. This indicated that EBB could induce the endothelium 

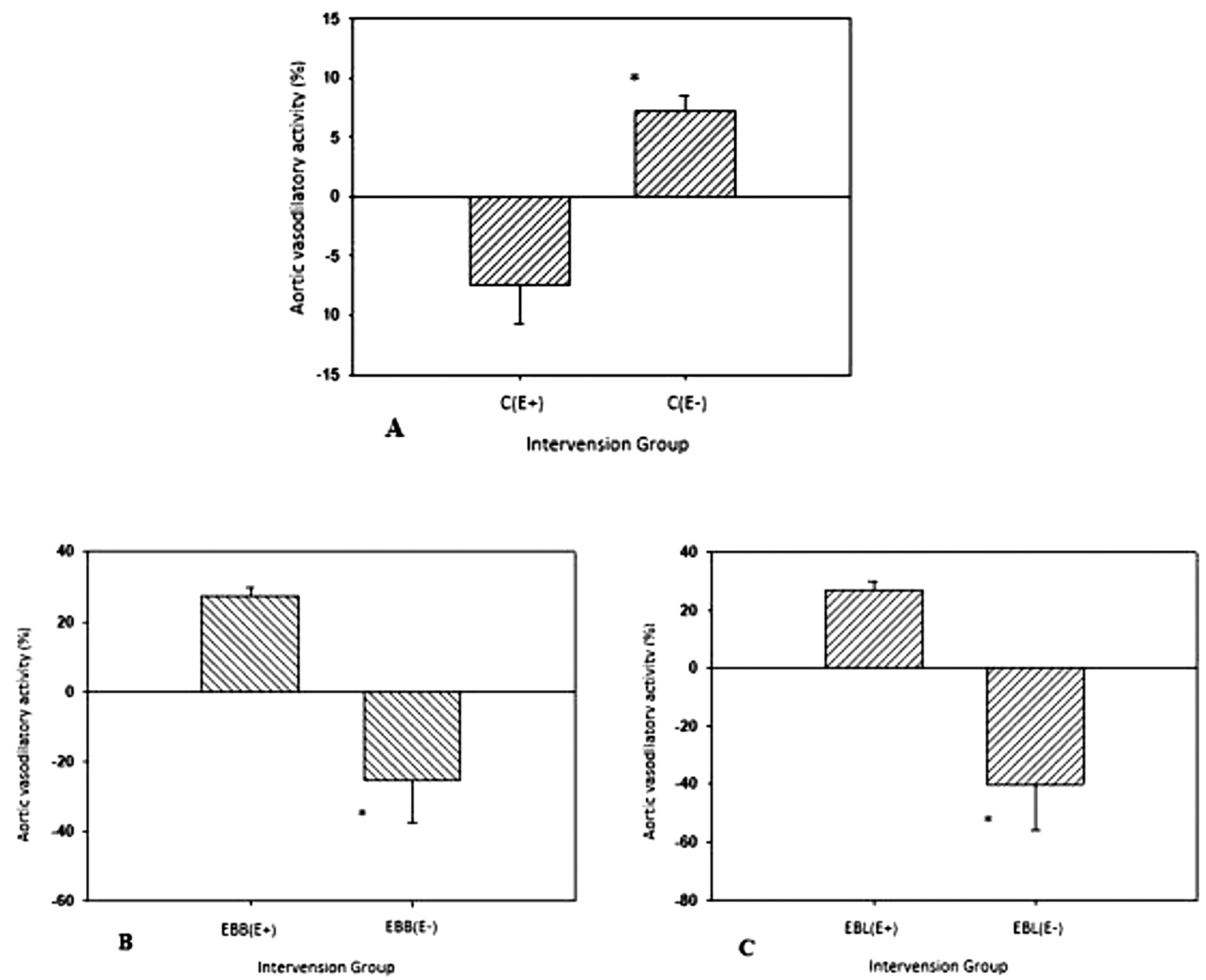

Figure 1. Vasodilatory activities of rat-isolated aorta rings with endothelium- and endothelium-denuded aorta following the intervention of the extract solvent (A); EBB (B); and $\mathrm{EBL}(\mathrm{C}) . \mathrm{n}=6$ rats; data are presented as mean $\pm \mathrm{SD} ; \mathrm{C}=$ control group $=$ extract solvent; $\mathrm{EBB}=E$. bulbosa bulb extract; $\mathrm{EBL}=E$. bulbosa leaf extract; (E+) $=$ aorta with endothelium; $(\mathrm{E}-)=$ endothelium-denuded aorta; $* t$-test analysis revealed statistically significant differences $(p<0.05)$.

to release endothelium-derived contracting factors, which release substances provoking blood vessel contraction and EDRF, which cause vasodilation in blood vessels. EDRF activity can be used as an indicator of blood vessel dysfunction. Furthermore, EBL showed vasodilatory activity in endothelium-denuded rat aorta and vasoconstriction in aortas with intact endothelium (Fig. 1C), revealing statistically significant differences $(p<0.05)$ using the $t$-test. These results show that the vasodilatory effects of EBB and EBL were not affected by solvent extracts that induced contraction in the endothelium-denuded aorta.

Figure 2A shows the vasoconstriction induced by EBL and EBB in aorta with endothelium, which failed to demonstrate statistical significance $(p>0.05)$. As shown in Figure $2 \mathrm{~B}$, the vasodilatory activity of EBL in the endothelium-denuded aorta was stronger than that induced by EBB, with the $t$-test presenting statistically significant differences $(p<0.05)$.

The aorta is the largest artery among all blood vessels, demonstrating a structure similar to arteries and arterioles, as well as almost evenly distributed cholinergic and adrenergic receptors (Rameshrad et al., 2016). Therefore, the aorta is used to evaluate blood vessel dilatation in vitro. Moreover, the aorta can be easily prepared and installed in an organ bath when compared with other smaller arteries.

Before examining the aortic dilatation activity, each treatment was carried out with a precontraction, by administering a $10^{-3} \mathrm{M}$ submaximal concentration of $\mathrm{PE}$ to the prepared aorta
(Ismail and Yuniati, 2016; Ismail et al., 2013). PE is a selective $\alpha_{1}$ receptor agonist, activating $\alpha$-adrenergic receptors in blood vessels. Activation of $\alpha$-adrenergic receptors results in contractions that increase peripheral vascular resistance and blood pressure (Brunton et al., 2011). In the vascular smooth muscle, there are two types of $\mathrm{Ca}^{2+}$ transmembrane channels: receptor-operated calcium channels (ROCC) and voltage-dependent calcium channels (VDCC). PE activates ROCC and regulates extracellular $\mathrm{Ca}^{2+}$ influx, causing the aorta to contract topically. In addition, $\mathrm{PE}$ activates specific inositol-1,4,5-triphosphate $\left(\mathrm{IP}_{3}\right)$ receptor channels in the sarcoplasmic reticulum membrane and induces the release of $\mathrm{Ca}^{2+}$ from sarcoplasmic reticulum, thereby causing vascular smooth muscle contraction (Gan et al., 2016).

In this study, vasodilatory activities of EBB and EBL were observed in the aorta with and without endothelium. EBB and EBL demonstrated contraction in the rat aortic ring with endothelium, indicating that $\mathrm{EBB}$ and EBL did not induce endothelium to release nitric oxide or prostacyclin, or other EDRF, which is a vasodilator. On the other hand, EBB and EBL relaxed the PE-contracted aortic ring with endothelium-denuded, which showed that EBB and EBL were active in the vascular smooth muscle to inhibit calcium channels or to induce other mechanisms that reduce $\mathrm{Ca}$ influx, causing vasodilation. Further studies are required to find out the exact mechanism.

The vasodilatory activity is presumably owing to the phytochemicals in EBB and EBL. Previous investigations on 

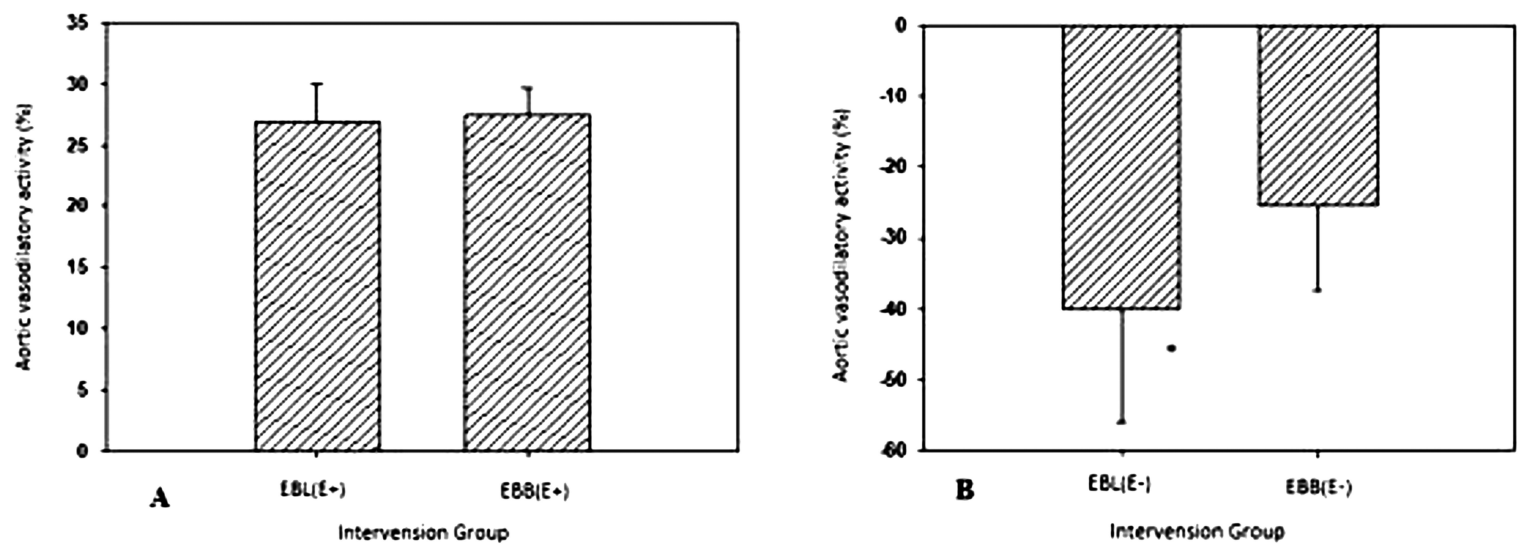

Figure 2. Comparison of vasodilatory activity of EBLs and EBBs in the isolated aorta with endothelium- (A) and endothelium-denuded (B) aorta. $\mathrm{n}=6$ rats; data are presented in mean $\pm \mathrm{SD} ; \mathrm{EBL}=E$. bulbosa leaf extract; $\mathrm{EBB}=E$. bulbosa bulb extract; $(\mathrm{E}+)=$ aorta with endothelium; $\left(\mathrm{E}^{-}\right)=$endothelium-denuded aorta; $* t$-test analysis revealed statistically significant differences $(p<0.05)$.

the bulbs of E. americana Merr. have confirmed that the bulbs contain alkaloids, flavonoids, glycosides, tannins, saponins, and triterpenoids/steroids compounds (Kamillah, 2014), with the leaves also revealing a similar composition of phytochemicals. Notably, the detected flavonoids, alkaloids, tannins, saponins, and triterpenoids are strongly suspected to play a role in blood vessel dilatation.

Reportedly, several studies have revealed that some flavonoid compounds can demonstrate a direct effect on the vascular smooth muscle. Flavonoids inhibit $\mathrm{Ca}^{2+}$ influx through inhibition of L-type $\mathrm{Ca}^{2+}$ voltage channels, with a reduced $\mathrm{Ca}^{2+}$ influx in smooth muscle cells resulting in vascular smooth muscle relaxation (Liu et al., 2014). For example, epigallocatechin-3-gallate, a flavonoid found in green tea, as well as in plants of the Malvaceae family, significantly reduces systolic blood pressure in hypertensive rats (Rezende et al., 2016); hesperetin, a flavonoid present in citrus, has a vasospasmolytic effect in rat coronary artery (Liu et al., 2014); and flavonoids isolated from Nolana ramosissima I.M. Johnst relax rat aorta through an endothelium-independent mechanism (Cifuentes et al, 2020) and can inhibit $\mathrm{Ca}^{2+}$ influx through $\mathrm{Ca}^{2+}$ L-type channels in VSMCs. Furthermore, flavonoids are known to inhibit the enzyme phosphodiesterase (PDE) in smooth muscle cells. In cells, PDE breaks down cyclic adenosine monophosphate (cAMP) and cyclic guanosine monophosphate (cGMP). In smooth muscle cells, high concentrations of cAMP and cGMP cause blood vessel dilation, as these molecules inhibit myosin light chain kinase. Additionally, PDE inhibition is directly related to the ability of flavonoids to block the calcium-calmodulin complex activity, suppressing the contraction of smooth muscle cells (Elvebak et al., 2010; Rezende et al., 2016). For example, quercetin, which is a flavonol triglycoside, a subclass of flavonoids, can increase cGMP concentrations through its role as an antioxidant in VSMCs, demonstrating a vasorelaxant effect in isolated rat aorta and porcine coronary arteries (Suri et al., 2010). Reportedly, quercetin levels are considerably high in the bulbs of $E$. americana Merr., making this plant a potential therapeutic agent (Rosa, 2013). Additionally, pure quercetin has been known to demonstrate a role in lowering blood pressure by inducing dilatation in blood vessels (PerezVizcaino et al., 2002). Quercetin can also inhibit vascular smooth muscle contraction by inhibiting the formation of angiotensin II, protein kinase activity, and blood vessel superoxide production (Ozarowski et al., 2018).

Notably, alkaloids demonstrate hypotensive and antihypertensive activities through vasodilator activity. For example, aristotelin, an indole alkaloid, derived from Aristotelia chilensis (Molina) Stuntz leaves, induces relaxation in endotheliumdenuded rat aorta by activating potassium channels and blocking calcium channels (Romero et al., 2019). Furthermore, alkaloids (tropane alkaloids), found in the roots of Erythroxylum lugens, can inhibit $\mathrm{Ca}^{2+}$ voltage channels and IP3 receptors in VSMCs. If the IP3 receptor on the surface of the sarcoplasmic reticulum of smooth muscle cells is activated, the sarcoplasmic reticulum will release $\mathrm{Ca}^{2+}$ intracellularly. The inhibition of these receptors results in decreased intracellular $\mathrm{Ca}^{2+}$ levels, preventing the formation of $\mathrm{Ca}^{2+}$-calmodulin complexes and resulting in the inhibition of actin and myosin cross-bridges (Oliviera et al., 2012).

Tannin is one of the phytochemicals present in the bulbs of E. americana Merr. (Noorcahyati, 2012). Tannins are divided into two groups, namely, hydrolyzed tannins and condensed tannins. Hydrolyzed tannins from the Geum japonicum L. plant affect NO and cGMP activities in rat aortic rings precontracted with PE. Tannins can induce the relaxation of blood vessels. Reportedly, the Moringa stenopetala leaf extract contains tannins and causes relaxation in spiral slices of the pig aortic, by blocking $\mathrm{Ca}^{2+}$ L-type channels in VSMCs (Geleta et al., 2016).

Saponins have also been reported to induce vasorelaxation in the rat aortic rings without endothelium, for example, ginsenoside $\mathrm{Rg}_{3}$, a ginseng saponin, which induces endotheliumindependent relaxation in rat aortic rings by inhibiting influx of $\mathrm{Ca}^{2+}$ and stimulating $\mathrm{K}^{+}$efflux (Gan et al., 2016). Astragaloside $\mathrm{IV}$, a saponin active ingredient extracted from Astragalus membranaceus, relaxes the endothelium-denuded rat aortic ring, through NO that comes from the vascular smooth muscle system (Hu et al., 2016).

Reportedly, terpenoids relax the endothelium-denude rat aortic rings. For example, the ethanol extract of Valeriana fauriei root and rhizome, which contains lots of sesquiterpenoids and iridoid glycosides, has vasodilatory activity in the endotheliumdenuded aortic ring, by blocking extracellular $\mathrm{Ca} 2+$ entry through ROCCs and VDCCs (Kim et al., 2019). Piperitenone 
oxide, a monoterpenoid ketone, as a major chemical constituent of the essential oil from Ziziphora clinopodioides Lam. (Uyghur traditional herb) and Mentha $x$ villosa, can relax the contraction induced by $\mathrm{PE}$ in both rat aortic rings with and without functional endothelium (Lan et al., 2017).

Based on the research reports above, flavonoids, alkaloids, tannins, saponins, and terpenoids have direct vasodilatory activity in vascular smooth muscle, not related to the endothelium. These chemical constituents can act synergistically with different strengths and amounts in each of the plant parts such as the bulbs and the leaves. In this study, showing that EBL induces a stronger vasodilatory activity compared to $\mathrm{EBB}$, it is suspected that the number of phytochemicals (flavonoids, alkaloids, tannins, saponins, and triterpenoids) which have vasodilatory activity in $\mathrm{EBL}$ is far more than those contained in EBB. Analogous to the studies reported above, the phytochemicals contained in EBL and EBB act on endothelial-independent VSMC. To prove the correct mechanism, further research is needed.

However, bioassay-guided isolation needs to be carried out to obtain active compounds possessing vasodilatory activity in the smooth muscle of blood vessels, as well as the continued elucidation of structures. Therefore, the bulbs and leaves of $E$. bulbosa are expected to be developed as an herbal antihypertensive agent acting on the smooth muscles of blood vessels.

\section{CONCLUSION}

The ethanol extract of bulbs and leaves of E. bulbosa possesses a vasodilatory effect in vitro by acting on the endotheliumindependent vascular smooth muscle. This vasodilatory activity of EBL was stronger than that induced by EBB.

\section{ACKNOWLEDGMENTS}

The authors are grateful to the Medical Faculty of Mulawarman University, Indonesia, for financial support as a research grant (no. 025/UN17.41/PT/2019).

\section{AUTHOR CONTRIBUTIONS}

All authors made substantial contributions to conception and design, acquisition of data, or analysis and interpretation of data; took part in drafting the article or revising it critically for important intellectual content; agreed to submit to the current journal; gave final approval of the version to be published; and agree to be accountable for all aspects of the work. All the authors are eligible to be an author as per the international committee of medical journal editors (ICMJE) requirements/guidelines.

\section{CONFLICTS OF INTEREST}

The authors report no financial or any other conflicts of interest in this work.

\section{ETHICAL APPROVALS}

The study protocol was approved by the Health Research Ethics Committee (KEPK) of Mulawarman University (No. 159/ KEPK-FK/IX/2019).

\section{PUBLISHER'S NOTE}

This journal remains neutral with regard to jurisdictional claims in published institutional affiliation.

\section{REFERENCES}

Brunton LL, Chabner BA, Knollmann BC. Goodman \& Gilman's the pharmacological basis of THERAPEUTICS. 12th edition, McGraw-Hill Medical, New York, NY, pp 277-95, 2011.

Cifuentes F, Palacios J, Borquez J, Paredes A, Parra C, Bravo A, Simirgiotis MJ. Fast isolation of flavonoids from the endemic species Nolana ramosissima I.M. Johnst and its endothelium-independent relaxation effect in rat aorta. Molecules, 2020; 25:520-37.

Couto C, Moraes D, Cartagenes M, Amaral F, Guerra R. Eleutherine bulbousa (Mill.) Urb.: a review study. J Med Plants Res, 2016; 10(21):286-97; doi:10.5897/JMPR2016.6106

Elvebak RL, Eisenach JH, Joyner MJ, Nicholson WT. The function of vascular smooth muscle phosphodiesterase III is preserved in healthy human aging. Clin Transl Sci, 2010; 3(5):239-42; doi:10.1111/ j.1752-8062.2010.00232.x

Gan L, Wang Z, Zhang H, Zhou X, Zhou H, Sun C, Si J, Zhou R, Ma C, Li J. Endothelium-independent vasorelaxant effect of 20(S)protopanaxadiol on isolated rat thoracic aorta. Acta Pharmacol Sin, 2016; 37:1555-62; doi:10.1038/aps.2016.74

Geleta B, Makonnen E, Debella A, Abebe A, Fekadu N. In vitro vasodilatory activity and possible mechanisms of the crude extracts and fractions of Moringa stenopetala (Baker f.) Cufod. leaves in isolated thoracic aorta of guinea pigs. J Exp Pharmacol, 2016; 8:35-42; doi:10.2147/ JEP.S117545

Hasimun P, Zakaria H, Susilawati E, Wardiono JD Antihypertensive activity ethanolic extract of bulb Eleutherine americana Merr. on fructose-induced hypertension rats. Int J Pharm Pharm Sci, 2017; 9(8):25-8; doi:10.22159/ijpps.2017v9i8.15383

Hu GY, Li XX, Zhang SY, Wang X. Association of rat thoracic aorta dilatation by astragaloside IV with the generation of endotheliumderived hyperpolarizing factors and nitric oxide, and the blockade of $\mathrm{Ca} 2+$ channels. Biomed Rep, 2016; 5:27-34; doi:10.3892/br.2016.680

Ismail S, Ali MM, Soeatmadji DW. Efek suplemen L-arginin subakut peroral pada kontraksi aorta tikus diabetes. J Exp Life Sci, 2013; 3(2):54-64; doi:10.21776/ub.jels.2013.003.02.02

Ismail S, Kosala K, Fikriah I, Magdaleni AR. Mechanism of vasorelaxation induced by Coptosapelta flavescens stems extract in rat thoracic aorta. J Trop Pharm Chem, 2017; 4(2):95-100; doi:https://doi. org/10.25026/jtpc.v4i2.146

Ismail S, Yuniati Y. Aktivitas vasodilatasi pembuluh darah secara in vitro dan uji toksisitas akut minuman fungsional herbal Kaltim. J Trop Pharm Chem, 2016; 3(3):197-201; doi:10.25026/jtpc.v3i3.107

Kamillah SN. Efektivitas ekstrak umbi Bawang Sabrang (Eleutherine palmifolia [L.] Merr.) terhadap pertumbuhan bakteri Streptococcus pyogenes. Univesitas Islam Negeri, Jakarta, Indonesia, 2014.

Kearney PM, Whelton M, Reynold K, Muntner K, Jiang H. Global burden of hypertension: analysis of worldwide data. Lancet, 2005; 365(9455):217-23; doi:10.1016/S0140-6736(05)17741-1

Kim B, Ma SS, Jo C, Lee S, Choi H, Lee K, Ham I, Choi HY Vasorelaxant effect of the ethanol extract from Valeriana fauriei briquet root and rhizome on rat thoracic aorta. Phcog Mag, 2019; 15(60):59-65; doi:10.4103/pm.pm_152_18

Lan W, Zhang HP, Wang Y, Jiang M, Li Q, An D. Antihypertensive effect of peperitenone oxide on spontaneously hypertensive rat by regulating calcium balance and reducing endothelin-1 secretion. Bangladesh J Pharmacol, 2017; 12:341-7; doi:10.3329/bjp.v12i3.32413

Liu Y, Niu L, Cui L, Hou X, Li J, Zhang X, Zhang M. Hesperetin inhibits rats coronary constriction by inhibiting $\mathrm{Ca}^{2+}$ influx and enchancing voltage-gated $\mathrm{K}^{+}$channel currents of the myocytes. Eur J Pharmacol, 2014; 735:193-201; doi:10.1016/j.ejphar.2014.03.057

Luna-Vázquez FJ, Ibarra-Alvarado C, Rojas-Molina A, RojasMolina I. Zavala-Sánchez MA. Review, vasodilator compounds derived from plants and their mechanisms of action. Molecules, 2013; 18:5814-57; doi:10.3390/molecules18055814

Mayasari D, Rusdiana T, KaniaYR, Abdasah M. Stability of Eleutherine americana (L.) Merr. extract as lipstick colorants as the change 
of temperatur, time, storage condition and the presence of oxidator. Indo $\mathrm{J}$ Pharm Sci Technol, 2018; 5(1):8-13; doi:10.24198/ijpst.v5i1.12864

Noorcahyati SH. Tumbuhan berkhasiat obat etnis asli kalimantan. Balai Penelitian Teknologi Konservasi Sumber Daya Alam, Balikpapan, Indonesia, p 77, 2012.

Oliviera AC, Sena-Filho JG, Mendes-Junior LG, Anjos RM, Riberio TP, Barbosa-Filho JM, Braga VA, Medeiros IA. Erythroxylum pungens elicits vasorelaxation by reducing intracelullar calcium concentration in vascular smooth muscle cells of rats. Braz J Pharmacogn, 2012; 22(2):436-42; doi:10.1590/S0102-695X2012005000005

Ozarowski M, Mikolajczak PL, Kujawski R, Wielgus K, Klejewski A, Wolski H, Seremak-MrozikiewiczA. Pharmacological effect of quercetin in hypertension and its potential application in pregnancy-induced hypertension: Review of in vitro, in vivo, and clinical studies. Evid Based Complement Alternat Med, 2018; 2018:1-19; doi:10.1155/2018/7421489

Perez-Vizcaino F, Ibarra M, Cogolludo AL, Duarte J. Endothelium-independent vasodilator effects of the flavonoid quercetin and its methylated metabolites in rat conductance and resistance arteries. J Pharmacol Exp Ther, 2002; 302(1):66-72; doi:10.1124/jpet.302.1.66

Pratiwi D, Wahdaningsih S, Isnindar. The test of antioxidant activity from bawang mekah leaves (Eleutherine americana Merr.) using DPPH (2,2-diphenyl-1-picrylhydrazyl) method. Trad Med J, 2013; 18(1):916; doi:10.22146/tradmedj.7755

Rameshrad M, Babaei H, Azzarmi Y, Fouladi DF. Rat aorta as a pharmacological tool for in vitro and in vivo studies. Life Sci, 2016; 145:190-204; doi:10.1016/j.1fs.2015.12.043

Rezende BA, Pereira AC, Cortes SF, Lemos VS. Vascular effect of flavonoids. Curr Med Chem, 2016; 23(1):87-102; doi:10.2174/0929867 323666151111143616

Romero F, Palacios J, Jofre I, Paz C, Nwokocha CR, Paredes A, Cifuentes F. Aristoteline, an indole-alkaloid, induces relaxation by activating potassium channels and blocking calcium channels in isolated rat aorta. Molecules, 2019; 24:2748.
Rosa LA. Penentuan Kuersetin dalam Bawang Dayak (Eleutherine americana Merr.) dengan Kromatografi Cair Kinerja Tinggi. Institut Pertanian Bogor, Bogor, Indonesia, 2013.

Sandoo A, Zanten JJCSV, Metsios GS, Caroll D, Kitas GD. The endothelium and its role in regulating vascular tone. Open Cardiovasc Med J, 2010; 4:302-12; doi:10.2174/1874192401004010302

Shi P, Du W, Wang Y, Teng X, Chen X, Ye L. Total phenolic, flavonoid content, and antioxidant of bulbs, leaves, and flowers made from Eleutherine bulbosa (Mill.) Urb. Food Sci Nutr, 2018; 7(1):148-54; doi:10.1002/fsn3.834

Suri S, Liu XH, Rayment S, Hughes DA, Kroon PA, Needs PW, Taylor MA, Tribolo S, Wilson VG. Quercetin and its major metabolites selectively modulate cyclic GMP-dependent relaxations and associated tolerance in pig isolated coronary artery. Br J Pharmacol, 2010; 159(3):566 75; doi:10.1111/j.1476-5381.2009.00556.x

Syamsul ES, Supomo S, Wijaya H, Nugroho BA. Ethanolic extract formulation of Bawang tiwai (Eleutherine americana) in antiacne cream. Trad Med J, 2015; 20(3):149-57. https://doi.org/10.22146/ tradmedj. 8860

Yuliandra Y, Oktarini R, Armenia A. Effect of Eleutherine americana Merr. bulb extract on blood pressure and heart rate in anesthetized hypertensive rats. J Sains Farmasi Klin, 2018; 5(2):119-25; doi:10.25077/ jsfk.5.2.119-125.2018

How to cite this article:

Fikriah I, Ismail S, Kosala K. In vitro evaluation of the vasodilatory activity of ethanol extracts of Eleutherine bulbosa bulbs and leaves. J Appl Pharm Sci, 2021; 11(05):135-140. 